\title{
Seasonal and diurnal characteristics of water soluble inorganic compounds in the gas and aerosol phase in the Zurich area
}

\author{
R. Fisseha ${ }^{1, *}$, J. Dommen ${ }^{1}$, L. Gutzwiller ${ }^{2}$, E. Weingartner ${ }^{1}$, M. Gysel ${ }^{1,3}$, C. Emmenegger ${ }^{4}$, M. Kalberer ${ }^{4}$, and \\ U. Baltensperger ${ }^{1}$ \\ ${ }^{1}$ Paul Scherrer Institut (PSI), 5232 Villigen, Switzerland \\ ${ }^{2}$ Bundesamt für Energie BFE, 3003 Bern, Switzerland \\ ${ }^{3}$ School of Earth, Atmospheric and Environmental Sciences, Univ. of Manchester, P.O. Box 88, Manchester M60 1QD, UK \\ ${ }^{4}$ Laboratory of Organic Chemistry, ETH Hönggerberg, CH8093 Zurich, Switzerland \\ *now at: ICG-II: Troposphäre, Forschungszentrum Jülich, 52425 Jülich, Germany
}

Received: 2 May 2005 - Published in Atmos. Chem. Phys. Discuss.: 10 August 2005

Revised: 9 May 2006 - Accepted: 12 May 2006 - Published: 1 June 2006

\begin{abstract}
Gas and aerosol samples were taken using a wet effluent diffusion denuder/aerosol collector (WEDD/AC) coupled to ion chromatography (IC) in the city of Zurich, Switzerland from August to September 2002 and in March 2003. The water soluble inorganic anions nitrate, sulfate, and nitrite were analyzed online with a time resolution of two hours for the gas and aerosol phase. The fraction of water soluble inorganic anions in PM10 varied from 15\% in August to about 38\% in March. Seasonal and diurnal variations of nitrate in the gas and aerosol phase were observed with more than $50 \%$ of the total nitrate in the gas phase during August and more than $80 \%$ of nitrate in the aerosol phase during March, in the latter case exceeding the concentration of sulfate by a factor of 2 . Aerosol sulfate, on the other hand, did not show significant variability with season. However, in the gas phase, the $\mathrm{SO}_{2}$ concentration was 6.5 times higher in winter than in summer. Nitrous acid (HONO) also showed a diurnal variation in both the gas and aerosol phase with the lowest concentration $\left(0.2-0.6 \mu \mathrm{g} / \mathrm{m}^{3}\right)$ in the afternoon. The mixing ratios of the primary pollutants, $\mathrm{NO}, \mathrm{CO}$ and $\mathrm{SO}_{2}$ were often at their highest between 4:00-10:00 local time due to the build up of fresh vehicle emission under a nocturnal inversion.
\end{abstract}

Correspondence to: U. Baltensperger

(urs.baltensperger@psi.ch)

\section{Introduction}

Air pollutants can cause adverse health effects (Gilli et al., 1988; Maynard, 2004; Pyne, 2002), loss of visibility through light scattering (Lee and Sequeira, 2002) and have the potential to cause other environmental damages (Morales et al., 1998). The effects of atmospheric aerosols depend on their size and chemical composition (Seinfeld and Pandis, 1998). Water soluble components comprise most of the aerosol fraction (Harrison et al., 2004; Querol et al., 2004). The two major inorganic water soluble compounds that play a key role in aerosol properties are sulfate and nitrate.

Non-sea salt sulfate is often the most dominant secondary inorganic aerosol component in the atmosphere. Sulfate particles are formed by oxidation of sulfur dioxide $\left(\mathrm{SO}_{2}\right)$ either in the gas phase or in water droplets (Finlayson-Pitts and Pitts, 2000). Most of the $\mathrm{SO}_{2}$ emissions globally result from fossil fuel burning. For this reason, most of the aerosol produced from the oxidation of $\mathrm{SO}_{2}$ is considered to be anthropogenic (Seinfeld and Pandis, 1998). In an increasing number of cases, nitrate is the most abundant component in fine particles (Magliano et al., 1999; Schaap et al., 2004). Nitrate may exist in the accumulation mode (mainly as ammonium nitrate), but may also exist in coarse particles due to deposition of nitric acid $\left(\mathrm{HNO}_{3}\right)$ on alkaline mineral or salt particles (Bassett and Seinfeld, 1984; Murphy and Thomson, 1997; Gard et al., 1998; Henning et al., 2003).

Sulfur and nitrogen containing aerosols are of interest to atmospheric studies due to their influence on radiative transfer and cloud formation, and hence on global climate (Charlson et al., 1992). Several authors reported the radiative and

Published by Copernicus GmbH on behalf of the European Geosciences Union. 


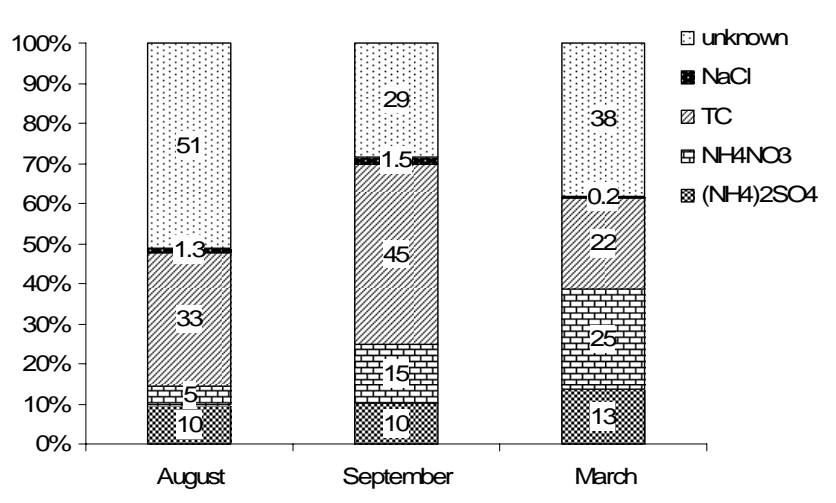

Fig. 1. Chemical composition of PM10 at Zurich Kaserne for the three months. The values in the bars indicate the percentage contributed by the component.

cloud formation effect of sulfate aerosol. However, until recently nitrate has not been considered in assessments of the radiative effects of aerosols. Van Dorland et al. (1997) suggested that radiative forcing due to ammonium nitrate is about one tenth of the sulfate forcing. However, the importance of aerosol nitrate could increase substantially over the next century. Observations and model results show that in regions of elevated $\mathrm{NO}_{\mathrm{x}}$ and $\mathrm{NH}_{3}$ emissions, such as Europe, and parts of North America, $\mathrm{NH}_{4} \mathrm{NO}_{3}$ aerosol concentrations may be quite high and actually exceed those of sulfate (Schaap et al., 2002; Christoforou et al., 2000; Wieprecht et al., 2004 ).

The composition of PM10 across Europe has been subject of a number of studies (Putaud et al., 2004; Turnbull et al., 2000; Querol, et al., 2001; Pakkanen, et al., 2001). In Switzerland, water soluble particulate inorganic compounds represent more than one-quarter of the average annual fine mass at both urban and rural sites (Hueglin et al., 2005). At urban sites in Switzerland, nitrate and sulfate account for $\sim 14 \%$ and $15 \%$ percent, respectively, of the annual-average fine particle mass (PM10). However, there is still a gap in measurements of gas phase precursors of these aerosol particulates, particularly nitric acid.

Nitrous acid (HONO) is an important precursor of the hydroxyl radical, the key oxidant in the degradation of most air pollutants in the troposphere. The sources of HONO are, however, still poorly understood (Kleffmann and Gavriloaiei, 2005). A breakthrough in the understanding of HONO formation may be the recent demonstration of photo-induced HONO production on humic acid (Stemmler et al., 2006).

This paper presents results from two field campaigns conducted in the center of Zurich in summer 2002 and winter 2003. The study involves on-line quasi-continuous chemical characterization of particulate and gas-phase inorganic anions using a wet effluent diffusion denuder/aerosol collector (WEDD/AC) coupled to an ion chromatograph. This method is particularly of interest to nitrate measurements as it minimizes the artifact compared to filter sampling which often has artifacts due to vaporization (Schaap et al., 2004). In addition, the high time resolution of the online measurement helps to understand the diurnal variations of the gas and aerosol phase of the compounds which can be used for modeling.

\section{Experimental}

\subsection{Sampling site}

The city of Zurich is located in the north-eastern part of Switzerland. In 2003, Zurich city had a population of about 340000 and covered a total area of about $88 \mathrm{~km}^{2}$. The sampling was made at the Kaserne, an open space of $\sim 1000 \mathrm{~m}^{2}$ which is situated in the city center very close to the main train station (Zurich HB). The site is also used as air monitoring station by the Swiss national air pollution monitoring network (NABEL) and characterized as urban background site (Putaud et al., 2004; Hueglin et al., 2005). The sampling for this study was performed in a measuring van, located close to the NABEL station. Both the measuring van as well as the NABEL station were operated by the Swiss Federal Laboratories for Materials Testing and Research (EMPA). Two sampling campaigns were made, the first one from 8 August to 30 September 2002 and the second from 3 to 30 March 2003.

\subsection{Methods}

Sampling for chemical analysis was performed with a wet effluent diffusion denuder/aerosol collector (WEDD/AC) which contains a flattened glass tube denuder with a dimension of $350 \mathrm{~mm} \times 3 \mathrm{~mm} \times 30 \mathrm{~mm}(\mathrm{~L} \times \mathrm{H} \times \mathrm{W})$ and an aerosol mixing chamber as described in Simon and Dasgupta (1993) and Zellweger et al. (1999). The inner surface of the denuder was coated with sodium silicate $\left(\mathrm{Na}_{2} \mathrm{Si}_{4} \mathrm{O}_{3}\right)$ and continuously wetted with ultra pure water $(18 \mathrm{M} \Omega \times \mathrm{cm}$, Millipore Milli-Q) at a flow rate of $1.5 \mathrm{ml} / \mathrm{min}$ using an Ismatec peristaltic pump in counter flow to the air. At the end of the denuder, the effluent was pumped to a trace concentrator column.

The particle collection system is based on the growth of particles under supersaturated conditions. In a mixing chamber (volume $250 \mathrm{ml}$ ) heated water vapor $\left(100^{\circ} \mathrm{C}\right.$, flow rate $0.6 \mathrm{ml} / \mathrm{min}$ ) was mixed with the air stream. The air is pumped further to a maze impactor, which is cooled down to $2^{\circ} \mathrm{C}$. The water vapor condenses on aerosol particles and grows to droplets, which impact on the maze. The particle containing liquid was collected and concentrated on a trace concentrator column before analysis by ion chromatography (IC). A more detailed description is found in Simon and Dasgupta (1995). Air samples were taken at a flow rate of $41 / \mathrm{min}$ through the WEDD/AC for $1 \mathrm{~h}$, and the resulting effluents from both the 

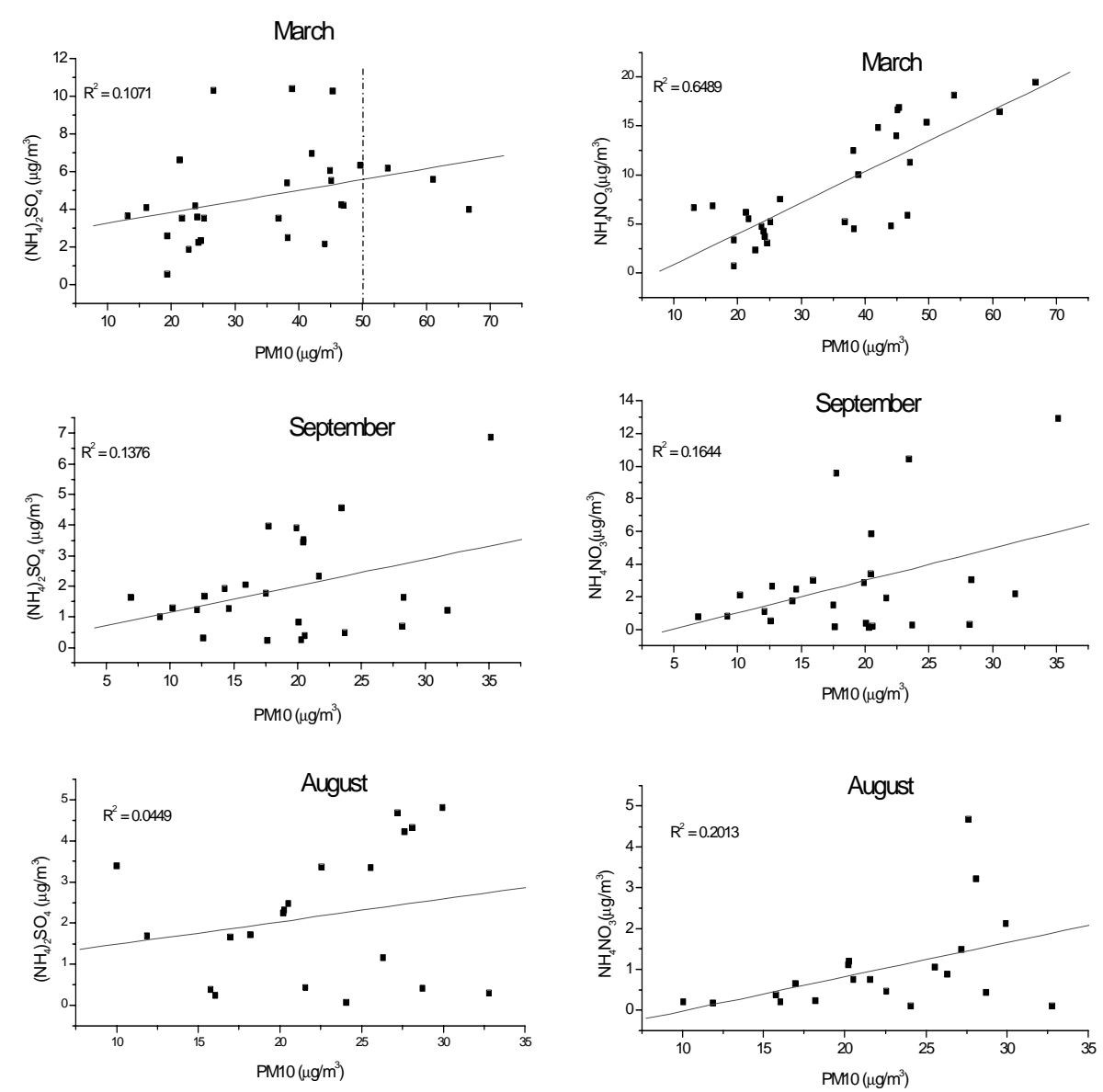

Fig. 2. Correlations of sulfate and nitrate (calculated as ammonium sulfate and ammonium nitrate, respectively) with PM10. The dotted line in the March sulfate graph indicates the current Switzerland daily concentration limit value for airborne particulate matter, which is $50 \mu \mathrm{g} / \mathrm{m}^{3}$.

denuder and aerosol collector were analyzed alternately using a Dionex ion chromatography system summarized in Table 1. Alternating analysis of the denuder and the particle collection system results in an overall temporal resolution of $2 \mathrm{~h}$.

For the total carbon content, aerosol samples were collected on quartz fibre filters $(150 \mathrm{~mm}$ diameter, Schleicher \& Schuell) with a high-volume sampler and a PM10 inlet at a flow rate of $0.5 \mathrm{~m}^{3} / \mathrm{min}$. Filters were sub-sampled by cutting out circles with a diameter of $14 \mathrm{~mm}$. An automated C/N analyzer (EA-1108, Carlo Erba) was used for the determination of total carbon (TC).

Aerosol size distributions were determined with a scanning mobility particle sizer (SMPS) (TSI Model 3071A) from 3 to 30 of March. The SMPS determined the size and number of the aerosols for mobility diameters between 14 and $740 \mathrm{~nm}$. The time resolution of the SMPS analysis was approximately $5 \mathrm{~min}$, from which 1 -h averages were calculated. In addition, meteorological parameters, ozone, NO, $\mathrm{NO}_{2}, \mathrm{CO}, \mathrm{SO}_{2}$ and PM10 were routinely determined at this
Table 1. Summary of the Dionex ion chromatography system used for online measurement of the anions.

\begin{tabular}{ll}
\hline Analytical column & AS 17, 4 mm \\
Guard column & AG 17, 4 mm \\
Pump & IP 20 \\
Detector & CD 25 (conductivity detector) \\
Eluent generator & EG40 eluent generator \\
Concentrator column & TAC-LP1 \\
Trap column & ATC-1 \\
Software & Peaknet 6.4 \\
Suppressor & ASRS, 4 mm \\
Valve & Rheodyne \\
\hline
\end{tabular}

station throughout the year. Data were provided by EMPA. Table 2 shows the methods and instruments used for the measurements of the above mentioned gaseous species and PM10. 
Table 2. Instruments used by the NABEL for gas and PM10 Measurements.

\begin{tabular}{lll}
\hline Compound & Method & Instrument \\
\hline $\mathrm{NO} / \mathrm{NO}_{2}$ & Chemiluminescence & Horiba APNA 360 \\
$\mathrm{Ozone}$ & UV-Absorption & TEI 49C \\
$\mathrm{CO}$ & Infrared-Absorption & Horiba APMA 360 \\
$\mathrm{PM10}$ & Beta gauge & Digitel DA-80H \\
$\mathrm{SO}_{2}$ & UV fluorescence & Monitor Labs 9850 \\
\hline
\end{tabular}

\subsection{Experimental uncertainties}

The limits of detection for all the inorganic anions determined by IC were in the range $0.2-3.5 \mathrm{ng}$, which corresponds to air concentrations of about $1-20 \mathrm{ng} / \mathrm{m}^{3}$ for a sampling time of $1 \mathrm{~h}$. In general, the concentrations of the ions determined by IC were sufficiently above the limit of detection. In some cases, when the concentrations of $\mathrm{HNO}_{3}$ was small $\left(<0.2 \mu \mathrm{g} / \mathrm{m}^{3}\right)$ the co-elution of the nitrate peak with carbonate made the quantification difficult. In these cases, the concentration of the $\mathrm{HNO}_{3}$ and aerosol nitrate could be overestimated by about $50 \%$.

\section{Results and discussion}

\subsection{PM composition}

A complete mass closure of PM10 in Switzerland is given by Hueglin et al. (2005). Figure 1 shows the chemical composition of PM10 measured at Zurich Kaserne in this study over the three months sampling period. In this plot TC (total carbon) refers to the sum of organic and elemental carbon. A factor of 1.4, based on Harrison et al. (2003) for urban background, was used to account for the mass of organic compounds. It is expected that this conversion factor experiences a seasonal dependence caused by changes in the relative contributions of primary and secondary organic compounds. Due to the absence of data to support the use of a seasonally varying ratio, a constant factor throughout the year was assumed. Sulfate was assumed to be present as ammonium sulfate, and particulate nitrate as ammonium nitrate. Chloride was assumed to be in the form of sodium chloride. The designation "unknown" applies to the difference between the mass concentration determined by the beta gauge and the sum of the species concentrations identified by chemical analysis. Silicates and calcium containing mineral dust, trace elements and water are among the materials not measured by the methods used in this study.

The composition of PM10 varied considerably from season to season. Carbonaceous aerosols represented the highest fraction (33\% in August, 45\% in September and 22\% in March) except for March where the nitrate contribution
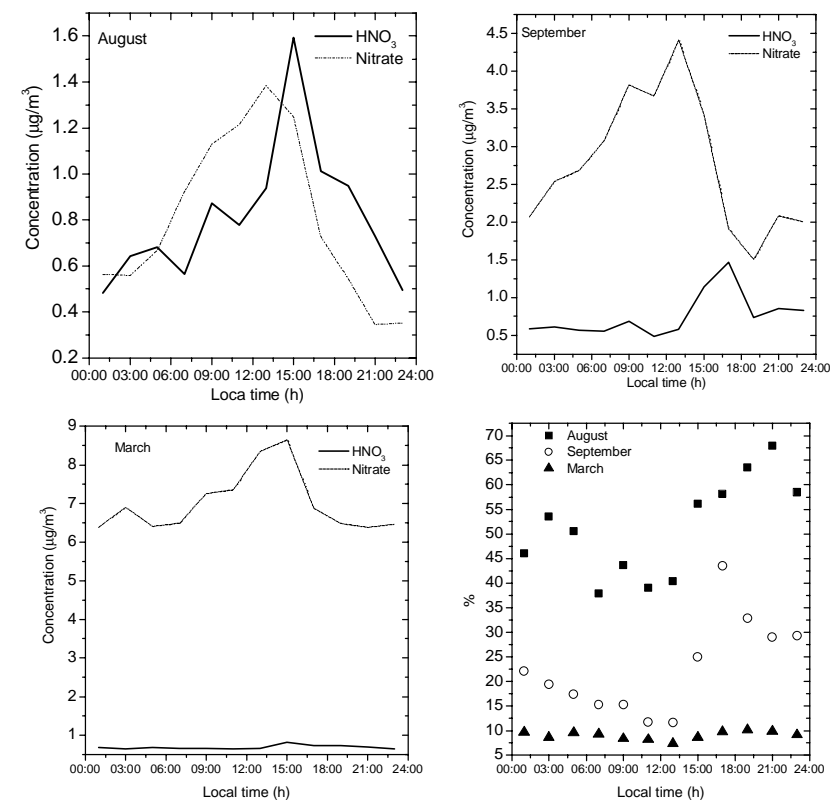

Fig. 3. Average diurnal variation of nitric acid and aerosol nitrate for the three months. The bottom right panel shows the contribution of gaseous nitric acid to total nitrate in percent.

was slightly higher. The seasonal average fraction of water soluble inorganic compounds varied from about $15 \%$ in August to about 38\% in March, with intermediate fractions in September. The percentage of nitrate in PM10 increased from summer to winter, showing a correlation with PM10 in March (Fig. 2). A similar observation was also reported by Querol et al. (2001). On the other hand, sulfate did not show a significant change in the contribution to the total PM10. The maximum contribution of sulfate was observed during March (13\%) and the minimum in August (10\%), and no correlation with PM10 is seen (Fig. 2).

The current Swiss limit value for airborne particulate matter comprises both an annual mean concentration $\left(20 \mu \mathrm{g} / \mathrm{m}^{3}\right)$ and a daily concentration of $50 \mu \mathrm{g} / \mathrm{m}^{3}$ which should not be exceeded more than once per year. This daily concentration limit was not exceeded during August and September. However, in March the concentration of PM10 was above the limit for at least three days (Fig. 2). In March, PM10 accumulation was associated with a lower height of the mixing layer, higher emissions due to room heating, and a higher particulate nitrate formation due to lower temperature as discussed below.

\section{2 $\mathrm{HNO}_{3}$ and aerosol nitrate}

\subsubsection{Diurnal variations}

The diurnal variations of particulate ammonium nitrate and gaseous $\mathrm{HNO}_{3}$ are shown in Fig. 3. In August, the two compounds were found to be about equally abundant. The 


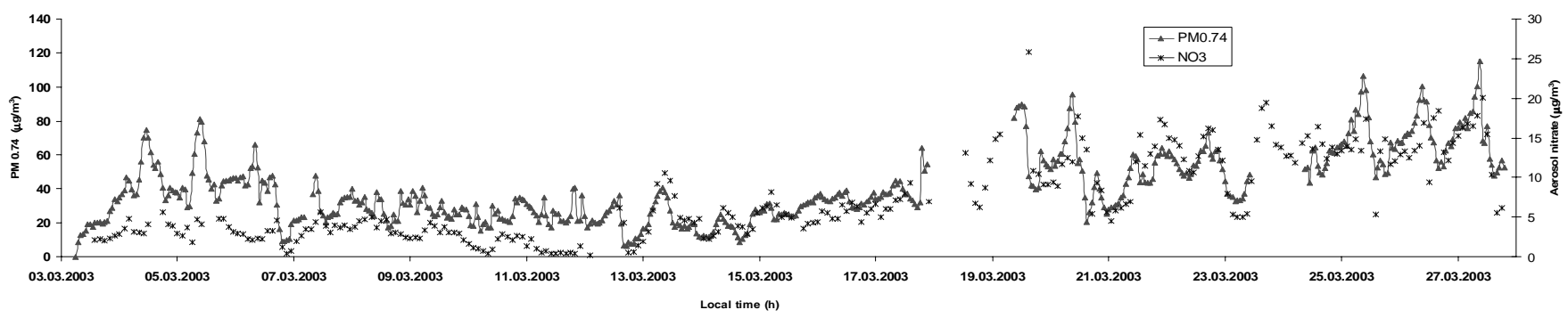

Fig. 4. Time series of PM0.74 and aerosol nitrate for March, 2003.

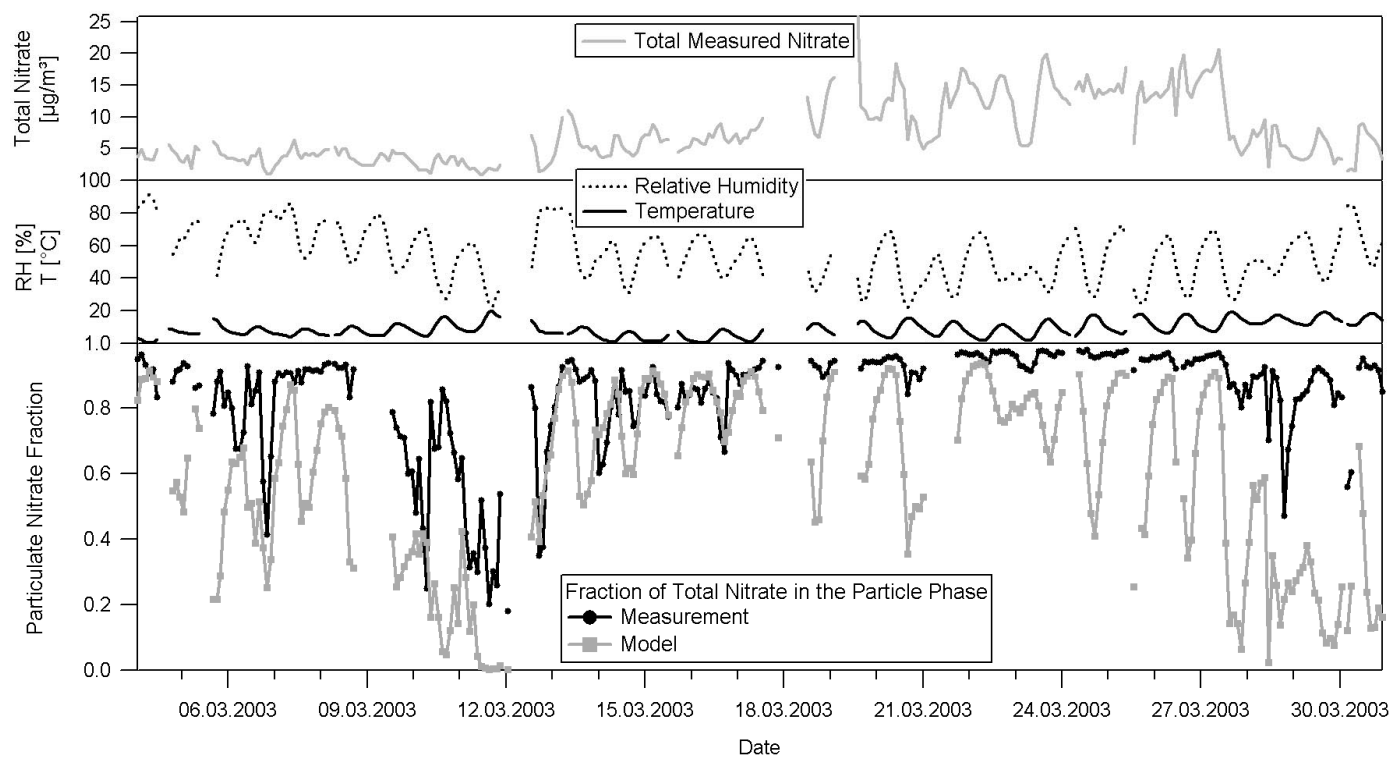

Fig. 5. Measured and modeled partitioning of nitrate between particle and gas phase (bottom panel). Total measured nitrate (top panel) and temperature and relative humidity (center panel) are also shown.

average observed concentration of nitric acid for August was $0.9 \mu \mathrm{g} / \mathrm{m}^{3}$ reaching a maximum of $1.6 \mu \mathrm{g} / \mathrm{m}^{3}$ in the afternoon when solar radiation was strongest and temperatures were highest. The aerosol nitrate peaked slightly earlier. Both components show a decrease in the afternoon due to dry deposition of $\mathrm{HNO}_{3}$ and an increase in early morning probably due to heterogeneous formation of nitrate. The maximum particulate nitrate concentration thus occurred in Zurich at 12:00 local time, which is four hours later than in Pittsburgh (Wittig et al., 2004). This time lag is explained by the temperature dependent partitioning of ammonium nitrate between the gas and aerosol phase. To get a rough estimate of the ammonium nitrate partitioning during the maximum temperature, the expression given by Stelson and Seinfeld (1982) for the equilibrium constant $\left(K_{p}\right)$ of the reaction between $\mathrm{HNO}_{3}$ and $\mathrm{NH}_{3}$ to form $\mathrm{NH}_{4} \mathrm{NO}_{3}$, was taken

$\mathrm{HNO}_{3}+\mathrm{NH}_{3} \leftrightarrow \mathrm{NH}_{4} \mathrm{NO}_{3}$
The equilibrium constant, $K_{p}$, of this reaction is given as the product of the partial pressures of $\mathrm{NH}_{3}$ and $\mathrm{HNO}_{3}$ by

$K_{p}=p_{\mathrm{NH}_{3}} * p_{\mathrm{HNO}_{3}}$

If $K_{p}\left[\mathrm{ppb}^{2}\right]<p_{\mathrm{NH}_{3}} * p_{\mathrm{HNO}_{3}}$, the system is supersaturated with ammonia and nitric acid, and a fraction of them will be transferred to the aerosol phase to establish equilibrium.

$K_{p}$ is temperature dependent and can also be expressed as (Seinfeld and Pandis, 1998)

$\ln K_{p}=84-(24220 / T)-6.1 \ln (T / 298)$

Where $T$ is the temperature in Kelvin and for a total pressure of $1 \mathrm{~atm}$.

$K_{p}$ was calculated from Eq. (2) at $T=22^{\circ} \mathrm{C}$ and fitted in Eq. (1) together with the measured $\mathrm{HNO}_{3}$ concentration $(0.6 \mathrm{ppb})$. Based on this equation, $11.8 \mathrm{ppb}$ of ammonia is required to reach equilibrium. If the concentration of ammonia or nitric acid exceeds this value, the equilibrium shifts 

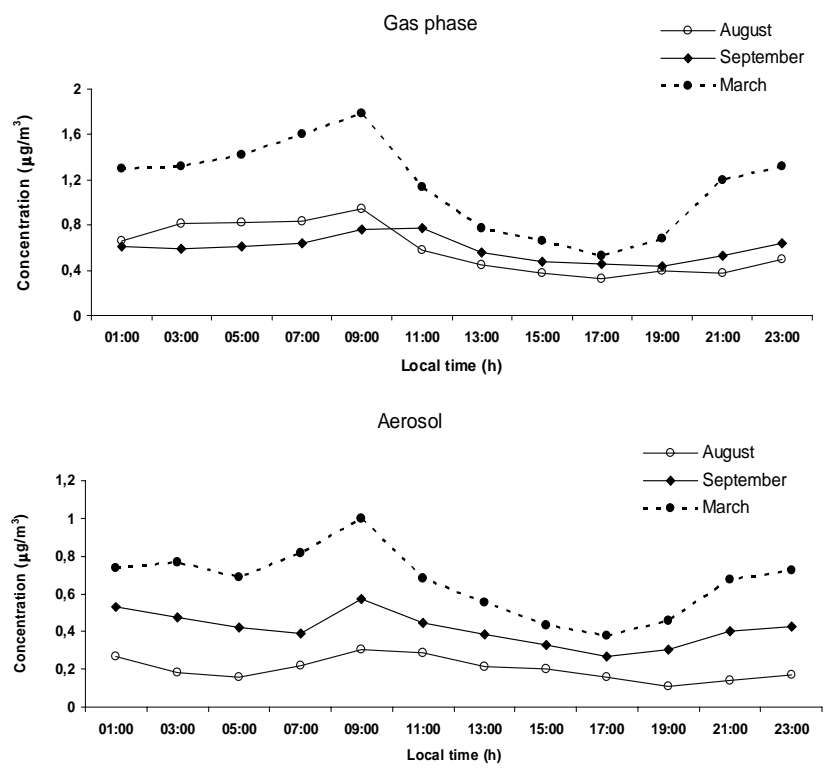

Fig. 6. Average diurnal variations of HONO in the gas and aerosol phase for the three months.

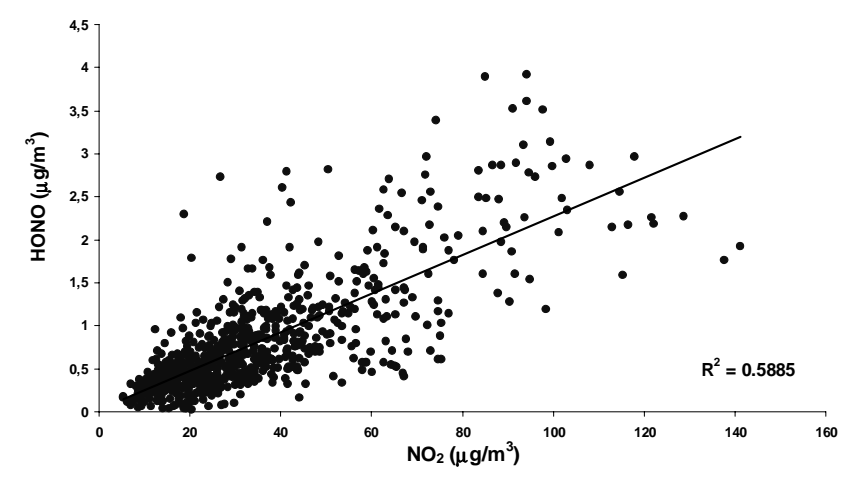

Fig. 7. Correlation of $\mathrm{HONO}$ with $\mathrm{NO}_{2}$.

towards the right resulting in formation of ammonium nitrate. The calculated ammonia was compared with measurement values given by (Emmenegger et al. (2004) for a tunnel entrance in Zurich city. The measured concentration at the tunnel entrance was much higher ( $36 \mathrm{ppb}$ ) compared to the calculated value, which implies that the formation of nitrate in Zurich city is very likely due to high ammonia concentrations.

\subsubsection{Seasonal variations}

A strong seasonal pattern of $\mathrm{NH}_{4} \mathrm{NO}_{3}$ and nitric acid was observed. The highest contribution of $\mathrm{NH}_{4} \mathrm{NO}_{3}$ to total nitrate was found in March (80\%) and the lowest in August (49\%). The contribution of nitrate to PM10 was also 5 times higher in March than in August. The total nitrate concentration (sum of nitrate and nitric acid) was also substantially higher in (a)
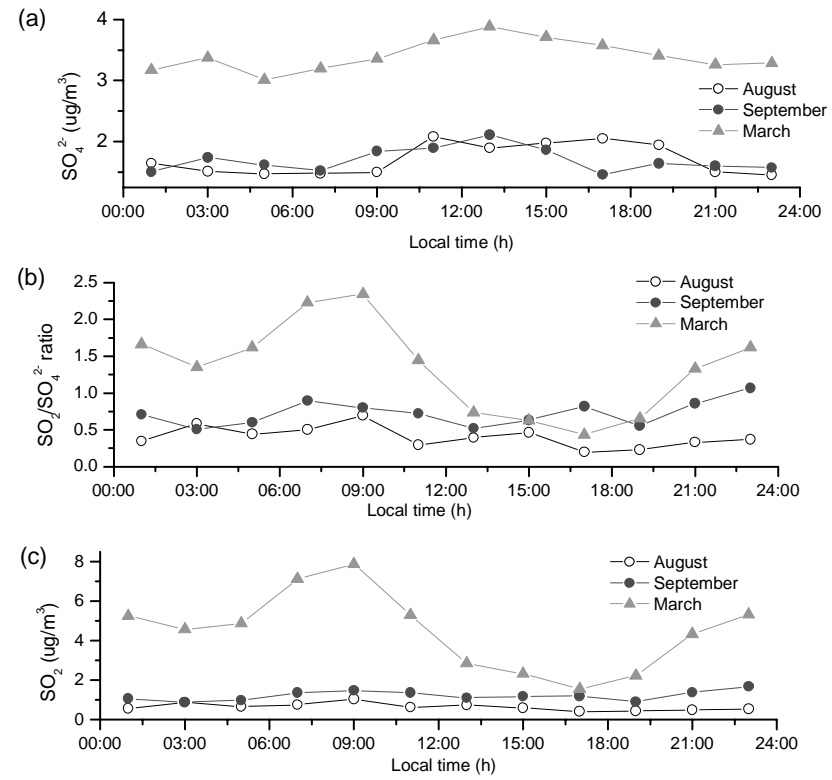

Fig. 8. A) Diurnal variations of the average $\mathrm{SO}_{4}^{2-}$ concentration for the three months. B) Diurnal variation of $\mathrm{SO}_{2} / \mathrm{SO}_{4}^{2-}$. C) Diurnal variation of the average $\mathrm{SO}_{2}$ concentration.

winter than in summer. Since photochemistry is less efficient during winter, the increase in total nitrate concentrations in winter is explained by efficient heterogeneous formation of nitrate on deliquesced aerosol particles and a longer lifetime of nitrate in winter than in summer due to the high dry deposition velocity of nitric acid. The concentration of nitrate in winter also showed a good correlation with submicron particles (PM0.74, see Fig. 4) $\left(r^{2}=0.52\right)$ determined from the integrated SMPS spectra assuming spherical particles with a density of $1.5 \mathrm{~g} / \mathrm{cm}^{3}$ (ammonium nitrate and sulfate have densities of 1.725 and $1.77 \mathrm{~g} / \mathrm{cm}^{3}$, respectively, which is reduced to some extent by carbonaceous compounds and water). This confirms that nitrate contributes substantially to PM0.74 in winter (Fig. 4).

\subsubsection{Comparison with model results}

The gas-particle partitioning of nitrate during March 2003 was further investigated using the Aerosol Inorganics Model II (AIM-II, http://www.hpc1.uea.ac.uk/ e770/aim. html, Clegg et al., 1998; Wexler and Clegg, 2002). The AIMII describes the $\mathrm{H}^{+}-\mathrm{NH}_{4}^{+}-\mathrm{SO}_{4}^{2-}-\mathrm{NO}_{3}^{-}-\mathrm{H}_{2} \mathrm{O}$ system including solid phases and partitioning of $\mathrm{NH}_{3}, \mathrm{HNO}_{3}$ and $\mathrm{H}_{2} \mathrm{SO}_{4}$ to the gas phase. The AIM determines the aerosol equilibrium state for a given amount of the above species by minimization of the Gibbs free energy of the system without simplifying assumptions. In this study sulfate, total nitrate, temperature and relative humidity measurements were available, and the aerosol was assumed to be fully neutralized with ammonia, that is $\left[\mathrm{NH}_{4}^{+}\right]=\left[\mathrm{NO}_{3}^{-}\right]+2\left[\mathrm{SO}_{4}^{2-}\right]$ in the model input. The 

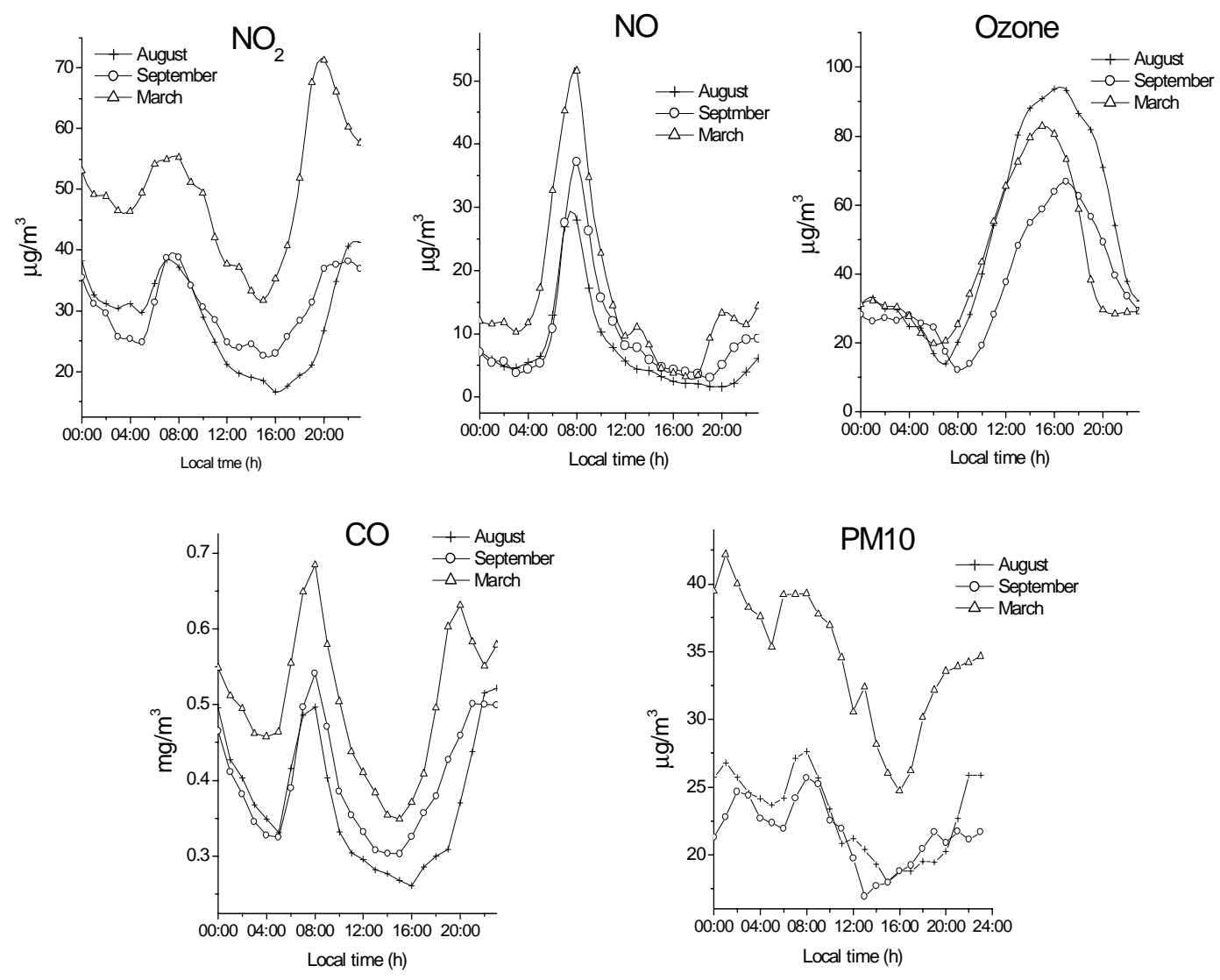

Fig. 9. Diurnal variations of gaseous pollutants and of PM10 for the three months.

aerosol was further assumed to be present as an aqueous solution, i.e. the formation of solids was turned off in the model calculations presented here. Model predictions including the solid phases were also made but predictions were similar to those for the aqueous aerosol.

The time series of the measured and modeled fraction of total nitrate in the particle phase along with the total nitrate, temperature and relative humidity is shown in Fig. 5. Low fractions of particulate nitrate were observed when the total nitrate loading was low, e.g. evening of 6 March, morning of 10 March, and 12 March, whereas high fractions of particulate nitrate coincided with high total nitrate loadings, e.g. from 19 March to 27 March. This reflects that $\mathrm{NH}_{3}$ and $\mathrm{HNO}_{3}$ start to partition to the particle phase in significant amounts only if their gas phase saturation concentration is exceeded. The dominating effect of varying total nitrate loadings is possibly one reason that no clear influence of the diurnal variations of temperature and relative humidity was observed, whereas diurnal cycles of ammonia concentrations might also be important. The model prediction captures the major trends of the nitrate partitioning reasonably well. However, the predicted particulate nitrate fraction is often lower than measured, and differences are typically larger during daytime. A main cause of that is probably that the atmospheric abundance of total ammonia is larger than the concentrations used in the model calculations thus driving more nitrate into the particle phase than predicted. Total ammonia concentrations used in the model runs ranged from 1 to $7 \mu \mathrm{g} / \mathrm{m}^{3}$, whereas ambient concentrations reported in Switzerland range from $3-7 \mu \mathrm{g} / \mathrm{m}^{3}$ at the rural site Payerne (EMEP station CH02) and up to about $25 \mu \mathrm{g} / \mathrm{m}^{3}$ (gas phase ammonia only) at a tunnel entrance in Zurich (Emmenegger et al., 2004). Furthermore, the tunnel entrance measurements showed a clear diurnal cycle with higher ammonia concentrations during daytime. This indicates that excess ammonia expected to be present in Zurich shifts the nitrate partitioning to the particle phase. Unfortunately, the AIM does not allow modelling with excess ammonia, that is $\left[\mathrm{NH}_{4}^{+}\right]>\left[\mathrm{NO}_{3}^{-}\right]+2\left[\mathrm{SO}_{4}^{2-}\right]$, which would provide an idea of the level of gas phase ammonia concentrations needed to explain the observed nitrate partitioning. It has also to be mentioned that part of the difference between observation and model calculation might arise from positive artifacts in particulate nitrate measurements due to organic nitrates or due to a disequilibrium state during the night caused by nitric acid production in aqueous particles through hydrolysis of $\mathrm{N}_{2} \mathrm{O}_{5}$. 
Table 3. Mean, median and standard deviations of the measured gas and aerosol compounds and PM10. The concentrations are all in $\mu \mathrm{g} / \mathrm{m}^{3}$ except $\mathrm{CO}$ which is in $\mathrm{mg} / \mathrm{m}^{3}$.

\begin{tabular}{|c|c|c|c|c|c|c|c|c|c|}
\hline \multicolumn{10}{|l|}{ August } \\
\hline & G-NO ${ }_{3}$ & $\mathrm{G}-\mathrm{SO}_{2}$ & $\mathrm{~A}-\mathrm{NO}_{3}$ & $\mathrm{~A}-\mathrm{SO}_{4}$ & $\mathrm{NO}_{2}$ & NO & $\mathrm{O}_{3}$ & $\mathrm{CO}$ & PM10 \\
\hline Mean & 0.81 & 0.68 & 0.83 & 1.71 & 28.6 & 7.4 & 49.1 & 0.37 & 22.9 \\
\hline Median & 0.55 & 0.41 & 0.40 & 1.53 & 25.3 & 3.0 & 46.3 & 0.33 & 22.6 \\
\hline $\mathrm{StDv}$ & 0.85 & 0.80 & 1.10 & 1.32 & 15.3 & 11.9 & 34.1 & 0.17 & 9.3 \\
\hline \multicolumn{10}{|c|}{ September } \\
\hline & G-NO ${ }_{3}$ & G-SO & $\mathrm{A}-\mathrm{NO}_{3}$ & $\mathrm{~A}-\mathrm{SO}_{4}$ & $\mathrm{NO}_{2}$ & $\mathrm{NO}$ & $\mathrm{O}_{3}$ & $\mathrm{CO}$ & PM10 \\
\hline Mean & 0.76 & 1.22 & 2.63 & 1.65 & 30.1 & 8.7 & 37.0 & 0.39 & 21.6 \\
\hline Median & 0.50 & 0.90 & 1.39 & 1.25 & 28.2 & 4.3 & 30.3 & 0.35 & 20.5 \\
\hline StDv & 0.71 & 1.18 & 3.22 & 1.43 & 13.9 & 15.1 & 26.9 & 0.16 & 10.5 \\
\hline \multicolumn{10}{|l|}{ March } \\
\hline & G-NO ${ }_{3}$ & G-SO & $\mathrm{A}-\mathrm{NO}_{3}$ & $\mathrm{~A}-\mathrm{SO}_{4}$ & $\mathrm{NO}_{2}$ & $\mathrm{NO}$ & $\mathrm{O}_{3}$ & $\mathrm{CO}$ & PM10 \\
\hline Mean & 0.69 & 4.07 & 6.85 & 3.37 & 50.6 & 16.5 & 41.8 & 0.51 & 34.5 \\
\hline Median & 0.63 & 2.87 & 4.10 & 2.89 & 44.3 & 5.0 & 40.9 & 0.43 & 30.6 \\
\hline $\mathrm{StDv}$ & 0.36 & 3.64 & 5.04 & 1.87 & 27.0 & 27.1 & 32.7 & 0.23 & 19.0 \\
\hline
\end{tabular}

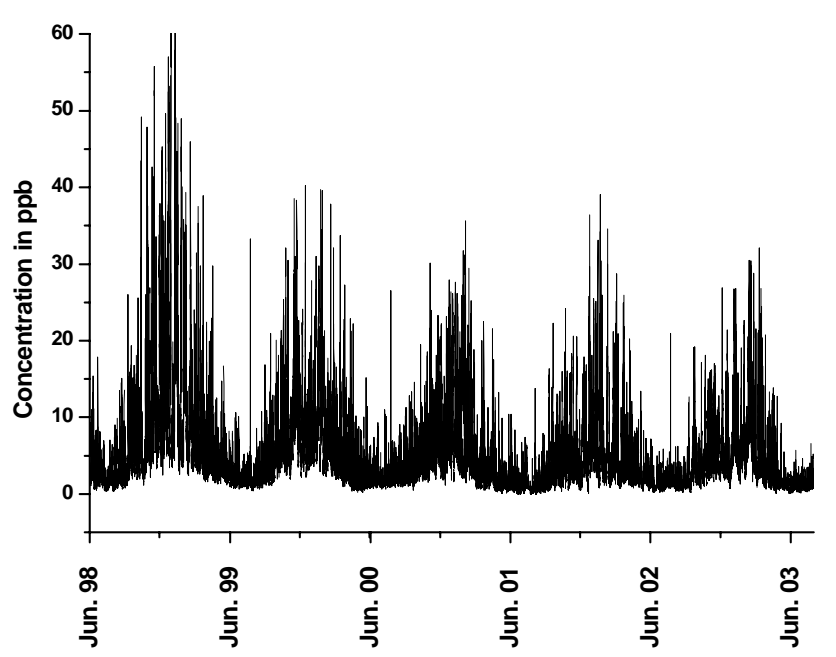

Fig. 10. Concentration of $\mathrm{SO}_{2}$ over a five-year period.

\subsection{Nitrous acid (HONO)}

HONO was measured in both campaigns in both the gas and the aerosol phase. It is well known that artifact HONO is formed from $\mathrm{NO}_{2}$ if an alkaline solution is used as scrubber solution in the WEDD/AC (Spindler et al., 2003), however, with MQ water as a scrubber solution, artifact $\mathrm{HONO}$ from $\mathrm{NO}_{2}$ is negligible (Simon and Dasgupta, 1995; Acker et al., 2004). In the gas phase, a diurnal variation of HONO is observed with an increasing concentration at night (Fig. 6). During the day the concentration of HONO decreased signif- icantly reaching a minimum between $0.2-0.6 \mu \mathrm{g} / \mathrm{m}^{3}$. These values as well as the diurnal patterns are comparable to the one reported by Kleffmann and Gavriloaiei (2005). Formation of HONO during night time has been observed in urban areas (Acker et al., 2004) and is attributed to heterogeneous reactions of $\mathrm{NO}_{2}$ on various surfaces. This heterogeneous formation and accumulation processes during the night lead to maximum values in the morning hours before photolysis causes a significant decrease. A similar trend was also observed for particulate nitrite, however with a less persistent increase during the night. The ratio of aerosol phase nitrite to total nitrite varied from $25 \%$ in August to $41 \%$ in September. Gaseous HONO concentrations were positively correlated with $\mathrm{NO}_{2}$, with an average $\mathrm{HONO} / \mathrm{NO}_{2}$ ratio of $2 \times 10^{-2}$ (Fig. 7). This value is significantly higher than the primary ratio from vehicles of $8.6 \times 10^{-3}$ as reported by Kurtenbach et al. (2001) indicating that heterogeneous formation processes such as the ones reported by Gutzwiller et al. (2002) contribute substantially to the total HONO concentration in Zurich. Furthermore, Stemmler et al. (2006) demonstrated recently that photo-induced HONO production on humic acid might contribute substantially to the daytime HONO concentrations.

\subsection{Sulfate and sulfur dioxide}

Figure 8 shows the diurnal variations of the measured particulate $\mathrm{SO}_{4}^{2-}$ concentrations, the gas phase $\mathrm{SO}_{2}$ concentration, and the ratios between these two. The diurnal variation of $\mathrm{SO}_{2}$ was most pronounced in March. This is due to 
increased early morning emissions into a planetary boundary layer with a low mixing height. Other combustion products such as $\mathrm{CO}$ and $\mathrm{NO}$ also show similar variations over the day (Fig. 9). The strong seasonal variation of $\mathrm{SO}_{2}$ concentrations with highest values in March is explained by higher emissions due to room heating, lower mixing height of the planetary boundary layer, and less efficient oxidation to sulfate. Similar observations are also reported by Ruuskanen et al. (2003) and Altshuller (1984).

The average concentration of sulfate during the whole measurement period was $2.3 \mu \mathrm{g} / \mathrm{m}^{3}$. The highest concentration of sulfate was observed during March (Table 3), however, the sulfate contribution to PM10 stayed virtually constant (see above). The sulfate values shown here are lower than the annual average reported by Hueglin et al. (2005) for the same site $\left(3.6 \mu \mathrm{g} / \mathrm{m}^{3}\right)$ for the year $1998 / 1999$. This is explained by a general decrease in the $\mathrm{SO}_{2}$ emission over the last years as shown by the NABEL data from Zurich (Fig. 10). The ratio of $\mathrm{SO}_{2}$ to $\mathrm{SO}_{4}^{2-}$ was higher in winter than in summer (Fig. 8), due to lower concentrations of reactive species $\left(\mathrm{OH}, \mathrm{HO}_{2}\right.$ or $\left.\mathrm{RO}_{2}, \mathrm{O}_{3}\right)$ (Dudkin et al., 2002). The same reason also explains the diurnal variation rather showing a maximum during the day (Fig. 8).

\section{Conclusions}

Water soluble inorganic anions comprise on average more than one quarter of the total PM10. Nitrate contributes a larger fraction to PM10 in winter than in other seasons due to lower temperature. The value of nitrate also exceeds the one of sulfate during winter. The variations of nitrate were strongest, which is attributed to the temperature dependency of nitrate aerosol partitioning. In August with high ambient temperatures the nitric acid concentration was highest, and due to a higher deposition rate of $\mathrm{HNO}_{3}$ than particulate nitrate, the total nitrate concentration in August was lower compared to March. The data showed marked seasonal and diurnal variations for gaseous $\mathrm{HNO}_{3}, \mathrm{HONO}, \mathrm{SO}_{2}$, and their corresponding particulate phase except for sulfate.

Acknowledgements. This work is supported by the Swiss National Science Foundation. We thank C. Hueglin, Empa for providing the NABEL data.

Edited by: M. Ammann

\section{References}

Acker, K., Spindler, G., and Brüggemann, E.: Nitrous and nitric acid measurements during the INTERCOMP2000 campaign in Melpitz, Atmos. Environ., 38, 6497-6505, 2004.

Altshuller, A. P.: Atmospheric particle sulfur and sulfur dioxide relationships at urban and nonurban locations, Atmos. Environ., 18, 1421-1431, 1984.
Bassett, M. E. and Seinfeld, J. H.: Atmospheric equilibrium model of sulfate and nitrate aerosols-II. Particle size analysis, Atmos. Environ., 18, 1163-1170, 1984.

Charlson, R. J., Schwartz, S. E., Hales, J. M., Cess, R. D., Coakley, J. A., Hansen, J. E., and Hofmann, D. J.: Climate forcing by anthropogenic aerosols, Science, 255, 423-430, 1992.

Christoforou, C. S., Salmon, L. G. , Hannigan, M. P., Solomon, P. A., and Cass, G. R.: Trends in fine particle concentration and chemical composition in Southern California, J. Air Waste Manage. Assoc., 50, 43-53, 2000.

Clegg, S. L., Brimblecombe, P., and Wexler, A. S.: Thermodynamic model of the system $\mathrm{H}^{+}-\mathrm{NH}_{4}^{+}-\mathrm{SO}_{4}^{2-}-\mathrm{NO}_{3}^{-}-\mathrm{H}_{2} \mathrm{O}$ at tropospheric temperatures, J. Phys. Chem. A, 102, 2137-2154, 1998.

Dudkin, V. A., Rukhin, V. B., and Chizhov, Y .L.: Photochemical oxidation of sulfur dioxide in air in the presence of ozone. Theor. Found. Chem. Eng., 36(2), 172-175, 2002.

Emmenegger, L., Mohn, J., Sigrist, M., Marinov, D., Steinemann, U., Zumsteg, F., and Meier, M.: Measurement of ammonia emissions using various techniques in a comparative tunnel study, Int. J. Environ. Pollut., 22, 326-341, 2004.

Finlayson-Pitts, B. J. and Pitts Jr., J. N.: Chemistry of the Upper and Lower Atmosphere, Academic Press, San Diego, 2000.

Gard, E. E, Kleeman, M. J., Gross, D. S., Hughes, L. S., Allen, J. O., Morrical, B. D., Fergenson, D. P., Dienes, T., Galli, M. E., Johnson, R. J., Cass, G. R., and Prather, K. A.: Direct observation of heterogeneous chemistry in the atmosphere, Science, 279, 1184-1187, 1998.

Gilli, G., Bono, R., Calleri, M., Corrao, G., and Scursatone, V.: Air pollution and health: a descriptive study among populations of the urban area of Turin, Atmos. Environ., 22, 193-194, 1988.

Gutzwiller, L., Arens, F., Baltensperger, U., Gäggeler, H. W., and Ammann, M.: Significance of semivolatile diesel exhaust organics for secondary HONO formation, Environ. Sci. Technol., 36, 677-682, 2002.

Harrison, R. M., Jones, A. M., and Lawrence, R. G.: A pragmatic mass closure model for airborne particulate matter at urban background and roadside sites, Atmos. Environ., 37, 4927-4933, 2003.

Harrison, R. M., Jones, A. M., and Lawrence, R. G.: Major component composition of PM10 and PM2.5 from roadside and urban background sites, Atmos. Environ., 38, 4531-4538, 2004.

Henning, S., Weingartner, E., Schwikowski, M., Gäggeler, H. W., Gehrig, R., Hinz, K. P., Trimborn, A., Spengler, B., and Baltensperger, U.: Seasonal variation of water-soluble ions of the aerosol at the high-alpine site Jungfraujoch (3580 m asl), J. Geophys. Res., 108(D1), 4030, doi:10.1029/2005JD002439, 2003.

Hueglin, C., Gehrig, R., Baltensperger, U., Gysel, M., Monn, C., and Vonmont, H.: Chemical characterization of PM2.5, PM10 and coarse particles at urban, near-city and rural sites in Switzerland, Atmos. Environ., 39, 637-651, 2005.

Kleffmann, J. and Gavriloaiei, T.: Daytime formation of nitrous acid: A major source of $\mathrm{OH}$ radicals in a forest, Geophys. Res. Lett., 32, L05818, doi:10.1029/2005GL022524, 2005.

Kurtenbach, R., Becker, K. H., Gomes, J. A. G., Kleffmann, J., Lorzer, J. C., Spittler, M., Wiesen, P., Ackermann, R., Geyer, A., and Platt, U.: Investigations of emissions and heterogeneous formation of HONO in a road traffic tunnel, Atmos. Environ., 35, 3385-3394, 2001. 
Lee, Y. L. and Sequeira, R.: Water-soluble aerosol and visibility degradation in Hong Kong during autumn and early winter 1998, Environ. Pollut., 116, 225-233, 2002.

Magliano, K. L., Hughes, V. M., Chinkin, L. R., Coe, D. L., Haste, T. L., Kumar, N., and Lurmann, F. W.: Spatial and temporal variations in PM10 and PM2.5 source contributions and comparison to emissions during the 1995 integrated monitoring study, Atmos. Environ., 33, 4757-4773, 1999.

Maynard, R.: Key airborne pollutants-the impact on health, Sci. Tot. Environ., 334-335, 9-13, 2004.

Morales, J. A., Bifano C., and Escalona, A.: Atmospheric deposition of $\mathrm{SO}_{4}-\mathrm{S}$ and $\left(\mathrm{NH}_{4}+\mathrm{NO}_{3}\right)-\mathrm{N}$ at two rural sites in the Western Maracaibo Lake Basin, Venezuela, Atmos. Environ., 32, 3051-3058, 1998.

Murphy, D. M. and Thomson, D. S.: Chemical composition of single aerosol particles at Idaho Hill: Negative ion measurements, J. Geophys. Res., 102(D5), 6353-6368, 1997.

Pakkanen, T. A., Loukkola, K., Korhonen, C. H., Aurela, M., Mäkelä, T., Hillamo, R. E., Aarnio, P., Koskentalo, T., Kousa, A., and Maenhaut, W.: Sources and chemical composition of atmospheric fine and coarse particles in the Helsinki area, Atmos. Environ., 35, 5381-5391, 2001.

Putaud, J. P., Raes, F., Van Dingenen, R., Brüggemann, E., Facchini, M. C., Decesari, S., Fuzzi, S., Gehrig, R., Huglin, C., Laj, P., Lorbeer, G., Maenhaut, W., Mihalopoulos, N., Müller, K., Querol, X., Rodriguez, S., Schneider, J., Spindler, G., ten Brink, H., Torseth, K., and Wiedensohler, A.: A European aerosol phenomenology - 2: chemical characteristics of particulate matter at kerbside, urban, rural and background sites in Europe, Atmos. Environ., 38, 2579-2595, 2004.

Pyne, S.: Small particles add up to big disease risk, Science, 295, 1994, 2002.

Querol, X., Alastuey, A., Rodriguez, S., Plana, F., Ruiz, C. R., Cots, N., Massagué, G., and Puig, O.: PM10 and PM2.5 source apportionment in the Barcelona Metropolitan Area, Catalonia, Spain, Atmos. Environ., 35, 6407-6419, 2001.

Querol, X., Alastuey, A., Ruiz, C. R., Artinano, B., Hansson, H. C., Harrison, R. M., Buringh, E., ten Brink, H. M., Lutz, M., Bruckmann, P., Straehl, P., and Schneider, J.: Speciation and origin of PM10 and PM2.5 in selected European cities, Atmos. Environ., 38, 6547-6555, 2004.

Ruuskanen, T. M., Reissell, A., Keronen, P., Aalto, P. P., Laakso, L., Grönholm, T., Hari, P., and Kulmala, M.: Atmospheric trace gas and aerosol particle concentration measurements in Eastern Lapland, Finland 1992-2001, Boreal Environ. Res., 8, 335-349, 2003.

Schaap, M., Spindler, G., Schulz, M., Acker, K., Maenhaut, W., Berner, A., Wieprecht, W., Streit, N., Müller, K., Brüggemann, E., Chi, X., Putaud, J.-P., Hitzenberger, R., Puxbaum, H., Baltensperger, U., and ten Brink, H.: Artifacts in the sampling of nitrate studied in the "INTERCOMP" campaigns of EUROTRACAEROSOL, Atmos. Environ., 38, 6487-6496, 2004.
Schaap, M., Müller K., and ten Brink, H. M.: Constructing the European aerosol nitrate concentration field from quality analysed data, Atmos. Environ., 36, 1323-1335, 2002.

Seinfeld, J. H. and Pandis, S.N.: Atmospheric Chemistry and Physics, John Wiley \& Sons, Inc., New York, 1998.

Simon, P. K. and Dasgupta, P. K.: Wet effluent denuder coupled liquid/ion chromatography systems: annular and parallel plate design, Anal. Chem., 65, 1134-1139, 1993.

Simon, P. K. and Dasgupta, P. K.: Continuous automated measurement of the soluble fraction of atmospheric particulate matter, Anal. Chem., 67, 71-78, 1995.

Spindler, G., Hesper, J., Brüggemann, E., Dubois, R., Müller, Th., and Herrmann, H.: Wet annular denuder measurements of nitrous acid: laboratory study of the artifact reaction of $\mathrm{NO}_{2}$ with $\mathrm{S}(\mathrm{IV})$ in aqueous solution and comparison with field measurements, Atmos. Environ., 37, 2643-2662, 2003.

Stemmler, K., Ammann, M., Donders, C., Kleffmann, J., and George, C.: Photosensitized reduction of nitrogen dioxide on humic acid as a source of nitrous acid, Nature, 440, 195-198, 2006.

Stelson, A. W. and Seinfeld, J.H.: Relative humidity and temperature dependence of the ammonium nitrate dissociation constant, Atmos. Environ., 16, 983-992, 1982.

Stockwell, W. R., Watson, J. G., Robinson, N. F., Steiner, W., and Sylte, W. W.: The ammonium nitrate particle equivalent of NOx emissions for wintertime conditions in Central California's San Joaquin Valley, Atmos. Environ., 34, 4711-4717, 2000.

Turnbull, A. B. and Harrison, R. M.: Major component contributions to PM10 composition in the UK atmosphere, Atmos. Environ., 34, 3129-3137, 2000.

Van Dorland, R., Dentener, F. J., and Lelieveld, J.: Radiative forcing due to tropospheric ozone and sulfate aerosols, J. Geophys. Res., 102(D23), 28 079-21 100, 1997.

Wexler, A. S. and Clegg, S. L.: Atmospheric aerosol models for systems including the ions $\mathrm{H}^{+}, \mathrm{NH}_{4}^{+}, \mathrm{Na}^{+}, \mathrm{SO}_{4}^{2-}$, $\mathrm{NO}_{3}^{-}, \mathrm{Cl}^{-}, \mathrm{Br}^{-}$, and $\mathrm{H}_{2} \mathrm{O}$, J. Geophys. Res., 107, 4207, doi:10.1029/2001JD000451, 2002.

Wieprecht, W., Acker, K., Müller, K., Spindler, G., Brüggemann, E., Maenhaut, W., Chi, X., Hitzenberger, R., Bauer, H., and ten Brink H.: INTERCOMP2000: ionic constitution and comparison of filter and impactor, Atmos. Environ., 38, 6477-6486, 2004.

Wittig, A. E., Takahama, S., Khlystov, A. Y., Pandis, S. N., Hering, S., Kirby, B., and Davidson, C.: Semi-continuous PM2.5 inorganic composition measurements during the Pittsburgh air quality study, Atmos. Environ., 38, 3201-3213, 2004.

Zellweger, C., Ammann, M., Hofer, P., and Baltensperger, U.: $\mathrm{NO}_{\mathrm{y}}$ speciation with a combined wet effluent diffusion denuderaerosol collector coupled to ion chromatography, Atmos. Environ., 33, 1131-1140, 1999. 